\title{
EKSPLORASI SUMBERDAYA AIR TANAH DI DAERAH HANDIL BABIRIK KABUPATEN TANAH LAUT
}

\author{
Oleh : Teguh Prayogo \\ Peneliti Bidang Geografi Fisik di Pusat Teknologi Sumberdaya Mineral, BPPT
}

\begin{abstract}
Ground water is water located beneath the ground surface in soil pore spaces and in the fractures of lithologic formations. A unit of rock or an unconsolidated deposit is called an aquifer when it can yield a usable quantity of water. Ground water is alternative water to meet a demand of water supply, because the availability of surface water at an area is sometimes not enough to fulfill the need of drinking water, like occured in the Handil Babirik area. In this paper will be discribed concerning application of imaging resistivity technology for understanding characteristic and condition of ground water in Handil Babirik, Tanah Laut district, South Kalimantan Province. The result of survey in field, data processing, modelling and interpretation indicated that the existence of aquifer in Handil Babirik area is occupied between 30-40 meter depth and having a form of lens.
\end{abstract}

Keywords : Handil Babirik, ground water, imaging resistivity

\section{PENDAHULUAN}

\subsection{Latar Belakang}

Air merupakan salah satu sumberdaya alam yang sangat dibutuhkan oleh semua mahluk hidup di permukaan bumi. Selain untuk kebutuhan vital mahluk hidup, air juga banyak digunakan dibidang energi, pertanian, dan peternakan. Banyak daerah-daerah di Indonesia yang potensi airnya sedikit bahkan sampai terjadi kekeringan air akibat bencana alam maupun ulah manusia. Supaya keberadaan sumberdaya air lestari, perlu dilakukan eksplorasi dan pengelolaan serta pemanfaatannya harus efisien dan optimal.

Kebutuhan air bersih seringkali tidak bisa hanya dengan mengandalkan air permukaan, karena pada daerah tertentu air permukaan tersedia dalam jumlah yang terbatas. Ataupun kalau ada, kualitasnya masih belum cukup untuk dimafaatkan. Salah satu alternatif mengatasi kekurangan air adalah dengan cara melakukan pencarian sumberdaya air bawah tanah. Kedalamannya mungkin bisa mencapai 150 meter lebih, tetapi air tanah semacam ini cukup bisa diandalkan untuk memenuhi kebutuhan masyarakat.

Eksplorasi merupakan salah satu cara untuk mencari dan menghitung potensi sumberdaya alam khususnya sumberdaya air tanah. Pekerjaan eksplorasi dilakukan dalam beberapa tahapan yang dimulai dari studi pendahuluan, survei recoinnasissance (survei tinjau) sampai dengan eksplorasi detil. Metode Imaging Resistivity adalah salah satu metoda dalam teknologi eksplorasi (geofisika) dinamis yang dikembangkan untuk mendeteksi kondisi bawah permukaan hingga kedalaman 200 meter.

Metode ini cukup terbukti efektifitas penerapannya untuk melakukan hal tersebut diatas, sehingga berdasarkan diskusi, kajian literatur, kondisi dan keperluan di kabupaten Tanah Laut, maka metode imaging resistivity ini diaplikasikan untuk melakukan akuisisi data keberadaan air bawah permukaan. Salah satu problema yang muncul di daerah Handil Babirik kabupaten Tanah Laut adalah sulitnya mendapatkan air bersih bagi kehidupan penduduk sehari-hari. Hal ini terjadi karena sulitnya mendapatkan air yang siap dipakai. Pada tulisan ini akan dibahas mengenai eksplorasi sumberdaya air di daerah Handil Babirik, Kabupaten Tanah Laut dengan penerapaan teknologi eksplorasi yang ada.

\subsection{Tujuan}

Tujuan yang diharapkan dari penelitian ini adalah mengidentifikasi sumberdaya air di daerah Handil Babirik, dengan menerapkan teknologi Imaging resistivity sehingga didapatkan gambaran mengenai kondisi airnya.

\section{LOKASI PENELITIAN DAN KESAMPAIAN DAERAH}

Lokasi kegiatan penelitian eksplorasi sumberdaya air ini dilakukan di daerah Handil Babirik, kecamatan Kurau, Kabupaten Tanah Laut bagian barat sisi utara, dimana kabupaten Tanah Laut ini termasuk Propinsi Kalimantan Selatan dengan luas total daratan sekitar $3.631,35 \mathrm{~km}^{2}$ atau hanya $9,71 \%$ dibandingkan dengan luas wilayah Propinsi Kalimantan Selatan $1)$. 
Secara Geografis, kabupaten Tanah Laut terletak di antara 114을' $20^{\prime \prime}$ sampai dengan 11523'31" Bujur Timur dan 330'33" sampai dengan 4011'38" Lintang Selatan. Kabupaten Tanah Laut ini terletak di sebelah Selatan sisi barat dari Propinsi Kalimantan Selatan yang dibatasi oleh Laut Jawa (sisi sebelah barat dan selatan), Kabupaten Tanah Bumbu (sisi sebelah timur) dan Kabupaten Banjar (sisi sebelah utara) seperti terlihat pada Gambar 1 di bawah ini.

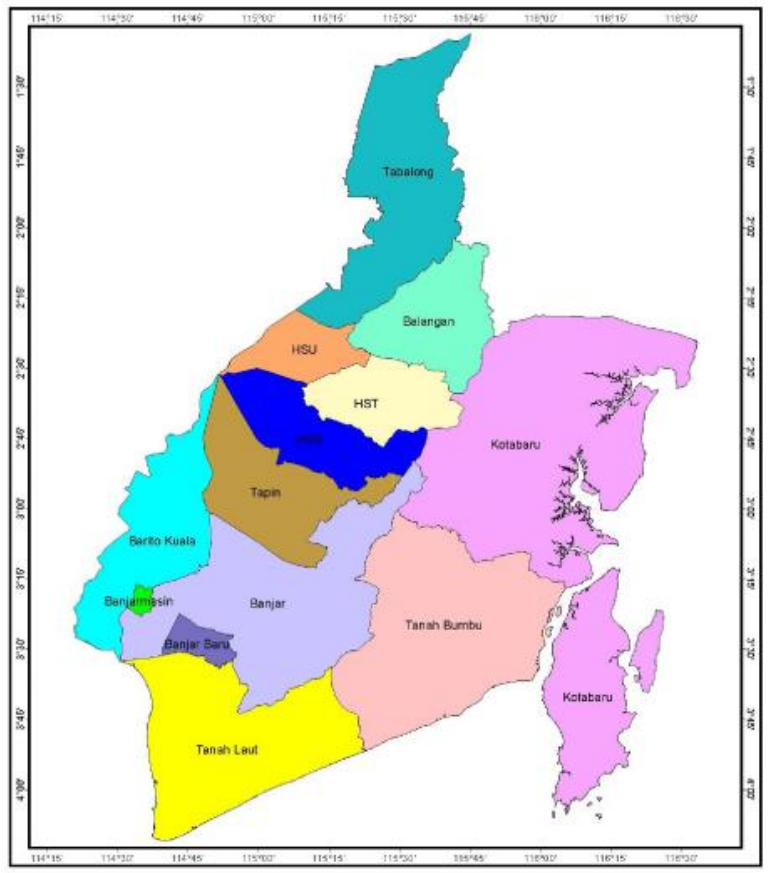

Gambar 1. Kabupaten Tanah Laut (Warna Kuning)

Daerah penelitian dapat dicapai dari Banjarmasin dengan menggunakan kendaraan roda 4 (mobil) atau kendaraan roda 2 (motor) melalui jalan trans Kalimantan dengan kondisi jalan yang relatif bagus dan beraspal. Waktu yang dibutuhkan dari Banjarmasin sampai ke ibukota Tanah Laut sekitar 1.5 - 2 jam.

Sementara itu, Desa Handil Babirik merupakan salah satu desa di kecamatan Kurau, yang terletak relatif di bagian tengah dari kecamatan Kurau dan masuk ke dalam ke arah barat dari jalan utama trans Kalimantan. Desa Handil Babirik ini berjarak sekitar $65 \mathrm{~km}$ dari kota Pelaihari, Ibukota Kabupaten Tanah Laut.

Lokasi survei eksplorasi sumberdaya air ini dapat ditempuh dengan menggunakan kendaraan roda 4 (mobil) atau kendaraan roda 2 (motor) dengan melewati jalan trans Kalimantan dan memerlukan waktu sekitar $1.5 \mathrm{jam}$. Kondisi jalan ke lokasi penelitian secara umum sangat baik yang terbuat dari aspal mix, dan sebagian dalam kondisi berlubang dan dalam perbaikan.

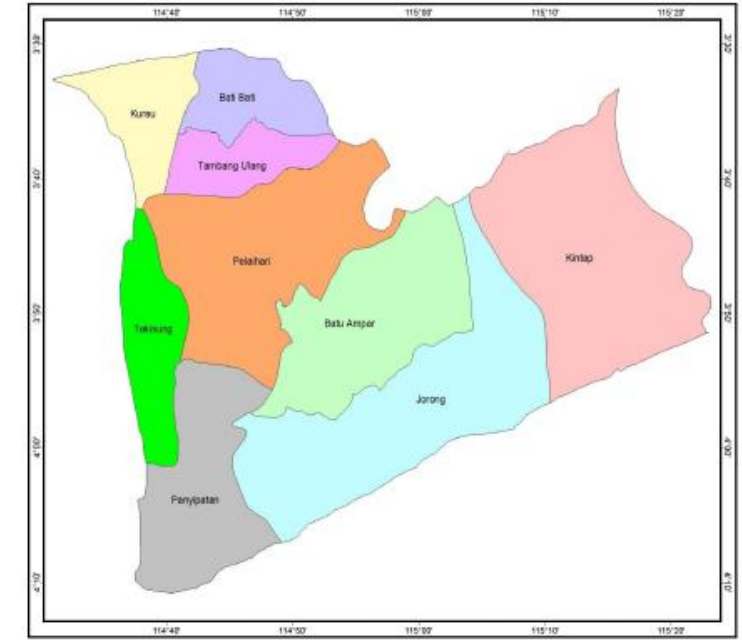

Gambar 2. Peta Administrasi Kabupaten Tanah Laut, Dimana Kecamatan Kurau Pada Sisi Utara Barat (Warna Kuning)

\section{METODOLOGI}

Metodologi yang diterapkan dalam penelitian ini secara garis besar terdiri dari studi pendahuluan, survei lapangan yang berupa survei imaging resistivity, dan analisis.

\subsection{Studi Pendahuluan}

Studi Pendahuluan ini dilaksanakan dengan melakukan kegiatan tinjauan pustaka, inventarisasi data dan informasi, pengadaan dan persiapan peta-peta dasar kerja, dan penentuan rencana survei (mobilisasi tim dan peralatan).

\subsection{Survei Lapangan}

Pekerjaan survei lapangan ini merupakan pekerjaan survei imaging resistivity yang ditrapkan pada daerah penelitian yang meliputi pembuatan lintasan geofisika, pemasangan elektroda, pengujian peralatan, pengukuran nilai tahanan jenis dan sebagainya. Survei imaging resistivity ini merupakan salah satu metoda geofisika dinamis yang dikembangkan untuk mendeteksi kondisi bawah permukaan (keberadaan akuifer) dengan menginjeksikan arus ke dalam bumi, selanjutnya di permukaan bumi diukur nilai kuat arus (I) dan beda potensial (V) titik-titik injeksi arus tersebut.

\subsection{Analisis}

Pekerjaan analisis ini dilakukan untuk memberikan gambaran tentang kondisi dan keberadaan air tanah (akuifer) secara 2 dimensi dengan melakukan pekerjaan penghitungan nilainilai terukur, pemodelan dan interpretasi hasil survei lapangan di daerah penelitian. 


\section{GEOLOGI DAERAH PENELITIAN}

Berdasarkan tinjauan terhadap peta geologi Propinsi Kalimantan Selatan, litologi daerah Kabupaten Tanah Laut berumur antara mesozoik, tersier dan kuarter ${ }^{3}$.

Secara fisiografis Kabupaten Tanah Laut terletak di bagian ujung Barat Daya Pegunungan Meratus dan di bagian Selatan Cekungan Barito dan Anak Cekungan Asam-Asam. Pegunungan Meratus terutama ditempati oleh batuan pra tersier, sedangkan Cekungan Barito da Anak Cekungan Asam-Asam ditempati oleh batuan sediment tersier.

Morfologi wilayah di Kabupaten Tanah Laut dapat dibagi menjadi 4 (empat) satuan morfologi yaitu Satuan Morfologi Dataran, Dataran Bergelombang, Perbukitan dan Pegunungan. Satuan Morfologi Dataran menempati bagian ujung Selatan dan ujung Barat. Ketinggian berkisar antara 0-10 m dpl.

Satuan ini berupa endapan alluvium rawa dan pantai yang tersusun dari batuan sediment kwarter. Satuan Morfologi Dataran Bergelombang menempati bagian Barat dan Selatan, yaitu sekitar jalur jalan raya Bati-bati Pelaihari - Asam-asam; Pelaihari - Batakan dan Pelaihari - Takisung.

Ketinggian berkisar antara $10-50 \mathrm{~m}$ dpl. Satuan ini tersusun oleh batuan sediment kwarter dan tersier. Satuan Morfologi Perbukitan menempati bagian tengah merupakan kaki dari Pegunungan Meratus. Ketinggian berkisar antara $50-250 \mathrm{~m}$ dpl. Satuan ini tersusun oleh batuan metamorf dn sediment serta sebagian kecil batuan beku.

Satuan Morfologi Pegunungan menempati bagian Utara, dicirikan oleh lereng yang terjal dengan ketinggian puncak lebih dari $250 \mathrm{~m}$ dpl. Beberapa puncaknya seperti Gunung Kematian (951 m dpl), Gunung Batu Belerang (921 m dpl), Gunung Batu Karo (621 m dpl).

\section{PERALATAN YANG DIGUNAKAN}

Peralatan yang digunakan pada penelitian eksplorasi sumberdaya air ini terdiri dari Global Positioning System (GPS), Kompas Geologi, Meteran, Digital Camera, dan Resistivitymeter merk OYO tipe Mc.Ohm 2115 A, kabel, elektroda dan geoscanner 1803, serta peralatan penunjang lainnya.

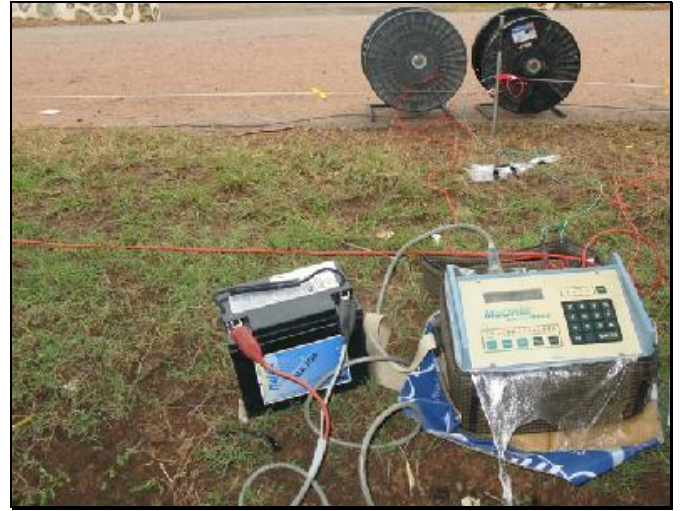

Gambar 3. Peralatan Survey Imaging Resistivity

\section{HASIL DAN PEMBAHASAN}

Pekerjaan survey geofisika pada kegiatan penelitian ini adalah difokuskan pada pekerjaan pendugaan sumberdaya air tanah, dimana komponen-komponen yang diamati dan diukur adalah nilai-nilai tahanan jenis bawah permukaan dari daerah yang diukur. Metoda yang dipergunakan dalam pengukuran geofisika ini adalah metoda 1D (Metoda Schlumberger). dimana hasil yang diharapkan adalah penetrasi yang lebih dalam yang digambarkan dalam 1 dimensi seperti lubang bor.

Pada metoda geolistrik 1D, pembahasan mengenai aliran listrik dalam bumi didasarkan pada asumsi bahwa bumi merupakan medium homogen isotropis. Jadi, lapisan batuan di bawah permukaan bumi diasumsikan berbentuk berlapis-lapis. Metoda schlumberger yang diterapkan adalah metoda Vertical electrical Sounding (VES). Pada metoda ini digunakan 2 elektroda arus dan 2 elektroda potensial, dimana susunan elektrodanya mempunyai spasi yang berubah-ubah 2). Hasil akhirnya adalah sebaran resistivity pada arah vertikal (seperti data bor). Masing-masing titik sounding selanjutnya dikorelasikan untuk interpretasi kedalaman akuifer di daerah penyelidikan. Visualisasi sistem pengukurannya dapat dilihat pada Gambar 4.

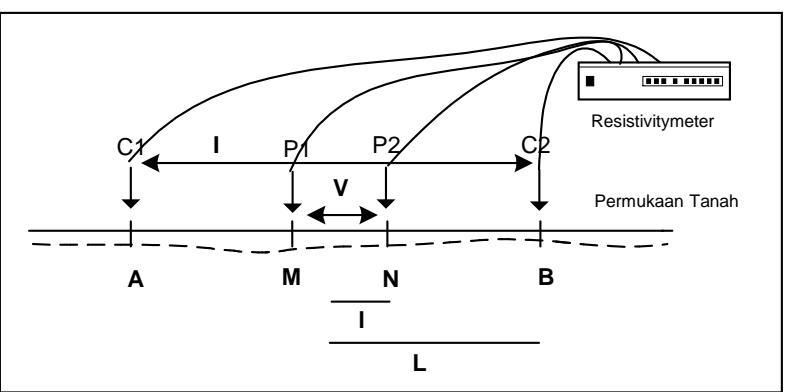

Gambar 4. Visualisasi Pengukuran Tahanan Jenis 1D Konfigurasi Schlumberger 
Dimana $\mathrm{M}, \mathrm{N}$ adalah elektroda potensial, sedangkan A dan B adalah elektroda arus. Untuk Konfigurasi Schlumberger, tahanan jenis didapatkan dari persamaan sebagai berikut :

$$
\rho_{s}=K_{s} \frac{\Delta V}{I} \quad \text { dan } \quad K_{s}=\frac{\pi\left(L^{2}-l^{2}\right)}{2 l}
$$

dimana $\rho$ adalah tahanan jenis semu, $\mathrm{K}$ adalah faktor geometri, I adalah besarnya arus listrik yang diinjeksikan ke dalam bumi, $\mathrm{V}$ adalah beda potensial yang terukur, $\ell$ adalah setengah spasi antara P1 - P2 (setengah jarak antara elektroda potensial), dan $L$ adalah setengah spasi antara C1 - C2 (setengah jarak antara elektroda arus).

Pekerjaan survei geofisika pada Desa Handil Babirik Kecamatan Kurau ini terdiri dari 3 titik pengukuran atau lintasan, dimana panjang total tiap lintasan sekitar 1000 meter. Secara umum arah lintasan geolistriknya berarah utara selatan atau sejajar dengan jalan atau relative sejajar arah utara peta seperti terlihat pada gambar 5 .

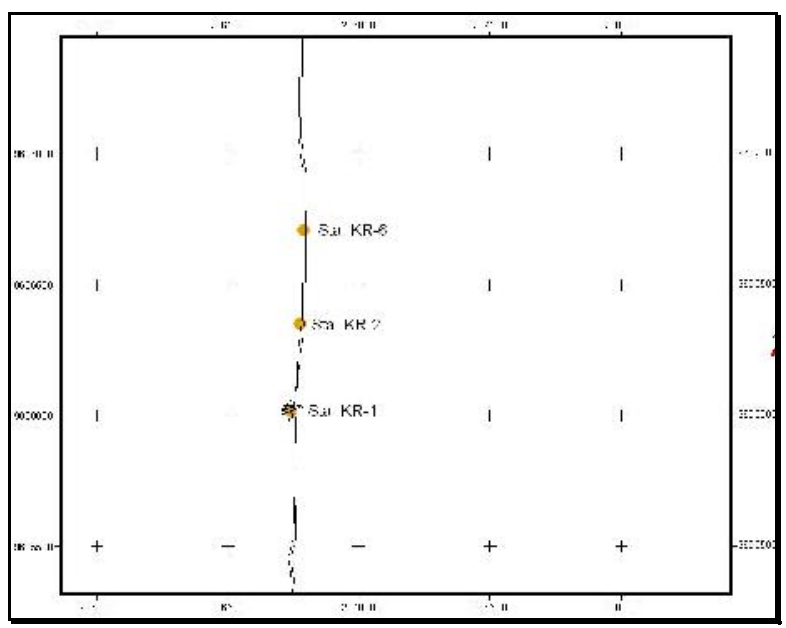

Gambar 5. Peta Lokasi Pengukuran Geofisika Di Daerah Handil Babirik, Kecamatan Kurau

Tabel 1. Titik-Titik Pengukuran Geofisika Di Daerah Handil Babirik, Kecamatan Kurau

\begin{tabular}{|l|l|c|c|}
\hline \multirow{2}{*}{ No } & \multirow{2}{*}{ Lokasi } & \multicolumn{2}{|c|}{ Koordinat } \\
\cline { 3 - 4 } & & Lintang & Bujur \\
\hline 1. & Sta.KR-1 & $3^{\circ} 33^{\prime} 41.1^{\prime \prime} \mathrm{S}$ & $114^{\circ} 37^{\prime} 49.1^{\prime \prime} \mathrm{E}$ \\
\hline 2. & Sta. KR-2 & $3^{\circ} 33^{\prime} 30.2^{\prime \prime} \mathrm{S}$ & $114^{\circ} 37^{\prime} 50.2^{\prime \prime} \mathrm{E}$ \\
\hline 3. & Sta. KR-6 & $3^{\circ} 33^{\prime} 18.7^{\prime \prime} \mathrm{S}$ & $114^{\circ} 37^{\prime} 50.6^{\prime \prime} \mathrm{E}$ \\
\hline
\end{tabular}

Karena pekerjaan survei imaging resisitivity ini terdiri dari 3 titik pengukuran atau lintasan, maka akan dihasilkan 3 kurva penampang tahanan jenis atau 3 kolom penampang tahanan jenis yang kenampakannya seperti log bor. Hasil pengukuran survei geofisika di lapangan tersebut diolah menggunakan suatu aplikasi untuk menghasilkan kurva tahanan jenis yang diplot pada kurva logaritma. Ketiga kurva hasil pengolahan tahanan jenis tersebut dapat dilihat pada gambar berikut :

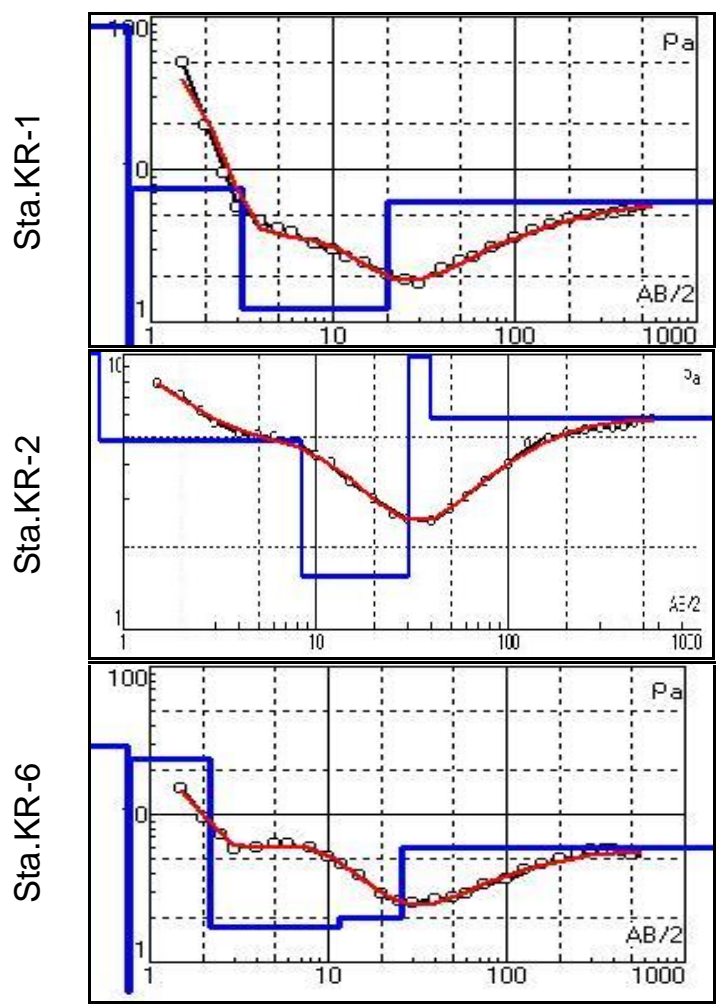

Gambar 6. Kurva Penampang Tahanan Jenis di 3 Lokasi Pengukuran Geofisika Di Daerah Penelitian

Kurva tahanan jenis yang dihasilkan dari pengeplotan pada kurva logaritma seperti Gambar 6 di atas, kemudian dibuatkan korelasi dengan nilai kedalaman dari permukaan tanah. Hubungan antara nilai tahanan jenis dan kedalaman pada 3 lokasi pengukuran geofisika di Kurau dapat ditunjukkan pada Gambar 7 di bawah ini.

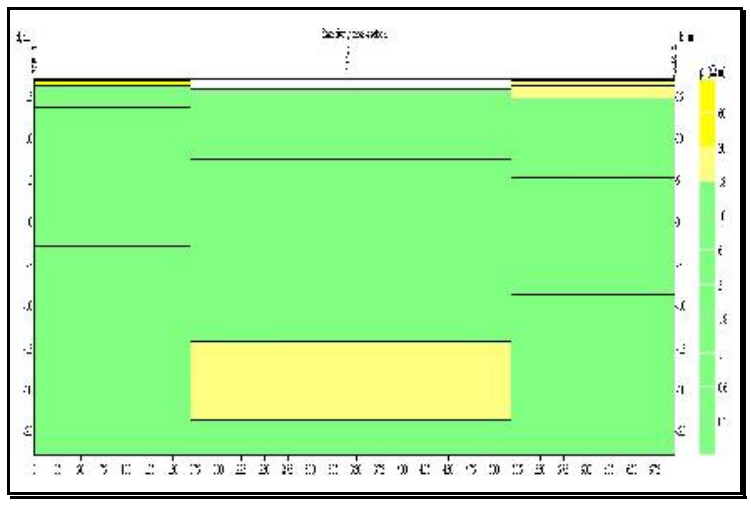

Gambar 7. Penampang Tahanan Jenis Di 3 Lokasi Pengukuran Geofisika Di Daerah Penelitian 
Berdasarkan hasil pemrosesan diatas, maka dihasilkan suatu penampang 1 dimensi (1D) yang menggambarkan segementasi kedalaman yang disertai dengan nilai tahanan jenisnya seperti terlihat pada Gambar 8 berikut ini :

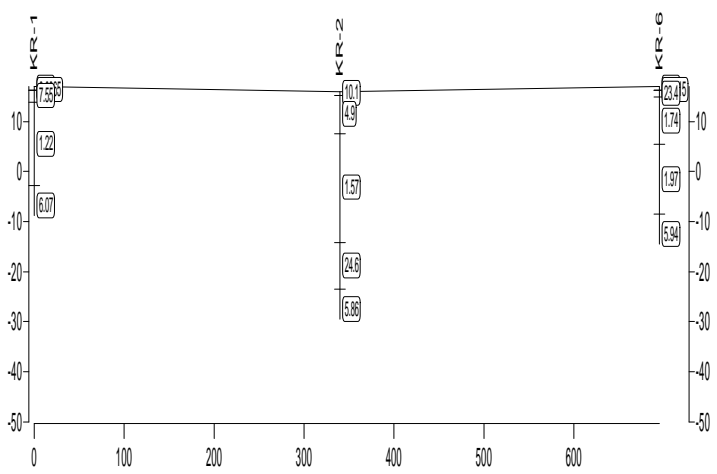

Gambar 8. Penampang 1 Dimensi Yang Menggambarkan Kedalaman Dan Nilai Tahanan Jenisnya

Selanjutnya dilakukan pekerjaan interpretasi dan analisa terhadap hasil pengolahan geofisika di atas dengan mengaitkan beberapa faktor yang bisa membantu dalam interpretasi, seperti kondisi geologi, kondisi lapangan, kondisi geohidrologi, dan lain sebagainya, guna mendapatkan model penampang geologinya, sehingga diperoleh gambaran tentang kondisi air tanah di daerah yang di teliti.

Pada Gambar 9 berikut memperlihatkan model penampang geologi yang merupakan hasil interpretasi dan analisa nilai tahanan jenis pada daerah Handil Babirik, Kecamatan Kurau. Warna Hijau mengindikasikan nilai tahanan jenis $<20$ $\mathrm{m}$, warna kuning menunjukkan tahanan jenis bernilai $20-29 \mathrm{~m}$, dan nilai tahanan jenis $>29$ $m$ diwakili dengan warna jingga.

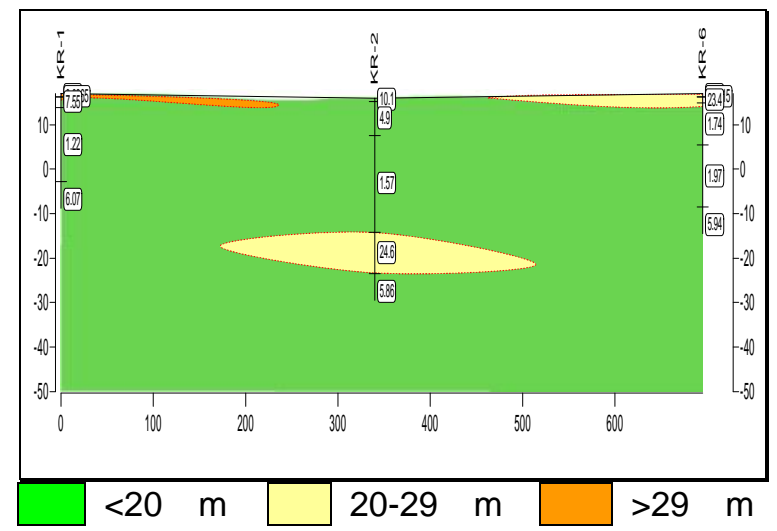

Gambar 9. Model Penampang Geologi Hasil Interpretasi Tahanan Jenis Di Daerah Penelitian
Berdasarkan hasil yang diperoleh dari pengukuran (survey) di lapangan, pengolahan data, dan pemodelan, maka dihasilkan nilai tahanan jenis yang bervariasi dari 20 Ohm-m sampai dengan 29 Ohm-m. Dengan mengacu kepada kondisi geologi daerah penelitian disertai dengan data referensi harga tahanan jenis beberapa batuan, maka dari harga-harga tahanan jenis tersebut dapat diinteroretasikan jenis litologi yang ada di daerah penelitian seperti terlihat pada Tabel 2 berikut.

Tabel 2. Nilai tahanan jenis dan interpretasi litologinya di daerah penelitian

\begin{tabular}{|c|l|}
\hline $\begin{array}{c}\text { Resistivity } \\
\rho \text { (Ohm-m) }\end{array}$ & Interpretasi Litologi \\
\hline$<20 \quad \mathrm{~m}$ & $\begin{array}{l}\text { Lempung atau air tanah } \\
\text { terintrusi }\end{array}$ \\
\hline $20-29 \mathrm{~m}$ & $\begin{array}{l}\text { Lanau, akuifer air tanah } \\
\text { (produktivitas rendah) }\end{array}$ \\
\hline$>29 \mathrm{~m}$ & $\begin{array}{l}\text { Endapan permukaan, } \\
\text { akuifer air tanah dangkal }\end{array}$ \\
\hline
\end{tabular}

Berdasarkan hasil survey geofisika dan pengolahan data tahanan jenis yang diperoleh seperti ditunjukkan pada Gambar 9, maka tampak bahwa di daerah penelitian didominasi sebagian besar oleh nilai tahanan jenis yang rendah $(<20 \quad \mathrm{~m})$ yang diinterpretasikan sebagai lapisan lempung (lapisan impermeable) dan sebagian kecil oleh tahanan jenis yang bernilai lebih besar yaitu $20-29 \mathrm{~m}$, yang diintepretasikan dengan litologi lanau. Sedangkan tahanan jenis yang bernilai > $29 \mathrm{~m}$ diinterpretasikan dengan endapan permukaan.

Lapisan batuan yang berpotensi sebagai akuifer air tanah adalah batuan yang mempunyai porositas dan permeabilitas cukup besar (misalnya lapisan pasir / batupasir). Berdasarkan hasil survey dan interpretasi tahanan jenis di daerah penelitian, kemungkinan terdapatnya air tanah adalah sebagai berikut :

Di lokasi daerah Handil Babirik Kecamatan Kurau ini, lapisan batuan yang berpotensi sebagai akuifer air tanah di lokasi Kurau-1 (Gambar 9 sisi kiri) tidak dijumpai, pada lokasi Kurau-2 (Gambar 9 sisi tengah) dapat dijumpai lapisan potensi pembawa akuifer air tanah pada kedalaman 30-40 m dan sedangkan pada lokasi Kurau-6 dijumpai lapisan tipis pada kedalaman 5-6 m (Gambar 9 sisi kanan). Dari data tersebut menunjukkan bahwa di daerah Handil Babirik Kecamatan Kurau mempunyai akuifer air tanah yang relatif dalam, karena lapisan permukaannya mempunyai lapisan lempung yang tebal (> $40 \mathrm{~m}$ ). 
Karena luas dan jumlah titik pengukuran tahanan jenis yang relatif sedikit/kecil disertai dengan tebalnya lapisan lempung yang ada di daerah penelitian, maka agak sulit untuk menafsirkan distribusi muka air tanah di daerah penelitian. Tetapi arah aliran air tanah dan air permukaan di daerah penelitian secara umum dapat ditafsirkan sebagai berikut :

Di Lokasi Handil Babirik Kecamatan Kurau, aliran air tanah tidak dapat diketahui karena lapisan yang berpotensi sebagai akuifer air tanah yang ditemukan berbentuk lensa pasir (tidak menerus).

\section{KESIMPULAN}

Berdasarkan hasil survey data tahanan jenis di lapangan, pengolahan data, pemodelan, analisis dan interpretasi di daerah Handil Babirik, Kecamatan Kurau, Kabupaten Tanah Laut, Propinsi Kalimantan Selatan, maka secara garis besar dapat disimpulkan sebagai berikut :

- Nilai tahanan jenis yang bervariasi dari 20 Ohm-m sampai dengan 29 Ohm-m.

- Lapisan potensi pembawa akuifer air tanah pada darah penelitian ditafsirkan berada pada kedalaman yang cukup dalam yaitu sekitar 30 - $40 \mathrm{~m}$, dimana bentuk cebakannya berupa lensa.

- Aliran air tanah tidak dapat diperkirakan karena lapisan yang berpotensi sebagai akuifer air tanah berbentuk lensa pasir (tidak menerus).

- Apabila akan dilakukan pemboran eksploitasi, maka untuk mendapatkan lapisan potensi akuifer air tanah bisa dilakukan pemboran di sekitar lokasi Kurau-2 pada kedalaman $30-40 \mathrm{~m}$ atau pemboran dalam dengan kedalaman diatas 150 meter.

- Karena hanya merupakan lensa pasir (volume kecil), maka apabila dilakukan pengambilan dianjurkan dengan debit yang kecil (< 1000 liter/hari)

- Pentingnya aplikasi teknologi Imaging Resistivity untuk eksplorasi sumberdaya air tanah dibeberapa daerah yang mengalami kesulitan air, sehingga ikut membantu menanggulangi permasalahan tersebut.

\section{DAFTAR PUSTAKA}

1. 2005, "Kabupaten Tanah Laut Dalam Angka 2005", Badan Pusat Statistik Kabupaten Tanah Laut, Badan Perencanaan Pembangunan Daerah.
2. Edwards L.S., 1977, "A modified pseudosection for resistivity and inducedpolarization. Geophysics", 42, 1020-1036.

3. N. Sikumbang \& R. Heryanto, 1994, "Peta Geologi Lembar Banjarmasin, Kalimantan (1712), Skala 1 : 250.000", Pusat Penelitian dan Pengembangan Geologi, Direktorat Jendral Geologi dan Sumberdaya Mineral, Departemen Pertambangan dan Energi. 